\title{
Globalization and Democracy: Challenges For Indonesia
}

\author{
Ignatius Ismanto \\ Social and Political Sciences, University of Pelita Harapan \\ Karawaci - Tangerang \\ ignatius.ismanto@uph.edu
}

\begin{abstract}
Indonesia has experienced a dramatic structural economic and political changes following the changing regional and global economy. A number of critical issues have encouraged the country in response to regional and global economic challenges: (i) economic crisis that hit Southeast Asia in 1997, (ii) ASEAN leaders' commitment to intensify their economic integration of ASEAN economy via ASEAN Economic Community (AEC), and (iii) Indonesia's leadership in ASEAN, especially in promoting regional economic forums that involve great powers in Asia, such as ASEAN-China Free Trade Area (ACFTA), ASEAN-Japan Comprehensive Economic Partnership, and ASEAN-India FTA. The changing regional and global economy will bring a very complicated political implication for a country.
\end{abstract}

For Indonesia, an economic crisis which hit the country in 1997 was a blessing in disguise. Without that, it is quite difficult to bring the dramatic social changes for the country, including the overthrown of the authoritarian rule. Economic crisis has promoted economic liberalization and weakened the ideas of protectionist economic policy. Indonesia's commitment inpromoting economic liberalization has also encouraged the country to take an active role in promoting regional economic forums. Indonesia uses ASEAN as a collective bargaining in response to the changing global economy. In this case, the establishment of AEC can be regarded as an instrument for ASEAN in response to the global economy. Unfortunately, Indonesia's commitment in encouraging a deeper economic integration of ASEAN has not been supported by its domestic politics in promoting the substantial democracy. Corruption has become a serious problem for the country in promotingdemocracy along with its commitment in response to globalization.

Keywords-globalization, corruption and democracy

\section{INTRODUCTION}

The monetary crisis that struck Asia in 1997 has brought about a widespread change in some countries in Southeast Asia. The crisis is now a meaningful lesson for the Developing Countries in
Asia. For Indonesia, the monetary crisis that developed into an economic crisis did weaken not only the legitimacy of President Suharto's government but also triggered the widespread demands of the masses to end the continuing power of the New Order's authoritarian regime, which has been maintained for a relatively long period of 32 years. There are a number of interesting issues from the phenomenon of the monetary crisis that eventually developed into a political crisis. First, seeing this monetary crisis from the economic dimension, the declining value of Indonesian Rupiah against uncontrolled foreign currency (in particular the US dollar) brought about the issue of foreign debt burden, the bankruptcy of a number of companies in the manufacturing sector, the widespread unemployment and worsening poverty. Second, the monetary crisis can also be seen from the political dimension. In this regard, the monetary crisis is often interpreted as a general distrust of the power regime. The distrust of the regime stems mainly from the widespread practice of corruption. The economic progress achieved by the New Order regime did not weaken the outbreak of corruption. However, the corruption does not seem to affect Indonesia's amazing economic growth. Why are corruption, the presence of authoritarian regimes, and economic growth likely to co-exist? Might the phenomenon be maintained amid the challenges of today's global economic change? This paper is intended to examine the challenges of Indonesia Post New Order in building democracy amid regional and global economic change.

II.GLOBALIZATION REGIONALIZATION

AND

This chapter focuses on the definition of globalization and how the developing countries respond to the process of globalization. Globalization is often viewed as the 'interconnectedness' and 'interdependentness' of countries in the global economy. Technological advancement has been the foundation of the globalization process. There are also other perspectives which consider the globalization process from another angle [1]. For instance, the first one, the Liberals assumed that the global system is in harmony which benefits all countries, even though the benefits are not the same for each 
country. Globalization is also a process in which countries cannot escape. Liberalists believe in the positive sum-game, and they believe that the globalization process will bring prosperity to the global economy. Also, Liberalists believe that by integrating developing countries into the globalization process, it will help developing countries develop and bring prosperity to the global economy. Secondly, from a Realist perspective, they believe that the global system is about conflicts. They see that globalization benefits the stronger countries and the weaker countries lose out during its process Realists focuses on the issue of power and security and they see globalization as a process that can be prevented by states if those states are willing. They see the global system as an 'anarchy' and the highest authority in the global system are the states. States are the main actors in the global arena, and each state has their interests in the global system. Realists also see relations between states as 'zero-sum' game which means the system itself benefits one state, and disadvantage another state. In relation to this, Realists, see that a state will support globalization if it strengthens their influence in the global system. On the contrary, a state will not support the globalization process if it endangers their national interests. Thirdly, the Structuralist-Marxists see the global system as exploitative. Globalization is the medium for the strong states to exploit the weaker states. According to the Structuralist-Marxists, it is an extension of the development of global capitalism. They see the globalization process as integrating developing countries into the globalcapitalistic system that will bring a slower development to the developing countries.

\section{POLITICAL ECONOMY OF INDONESIA}

Indonesia cannot escape from the globalization process. How does Indonesia deal with the changing global economy? Government's intervention in an economic sector is an important concept in Indonesia. This concept has been a dominating force in protectionist policies in the Indonesian economy for a long time. Despite that, an economic crisis in Indonesia opened up a chance for Indonesia to be more pragmatic in its economic policies. It opened up the market to play a more significant role in Indonesia's economy. This chapter analyzes economic policies in line with changes in the Indonesian economy.

The late industrialization and economic backwardness, in general, seems to be the main factor which causes the developing countries to choose protectionist economic policies. In the same manner, Gerschencorn in his thesis said that "the more economic backward a country is and the later a country industrializes that there is a need for government intervention in an economy to overcome economic backwardness and late industrialization." This consideration also explains the strengthening of Indonesia's protectionist economic policies since Indonesia escaped from a long period of colonialism. As a country that faced economic underdevelopment, national leaders tend always to emphasize the importance of the role and intervention of the state in overcoming its economic backwardness.

The consideration on the importance of the role and intervention of the state in economic activity has strongly influenced the economic policy of Indonesia, both at the beginning of the nation's independence, during President Soekarno's era and at the early days of Soeharto's New Order. Even during the reign of President Soekarno, the direction of the economic policies was to preventing the influence or dominance of foreign economic power which shows the strong influence of economic nationalism sentiment in the history of Indonesian economic development. The sentiment of economic nationalism which emphasized the importance of the state's role and intervention did not necessarily weaken even during the transfer of power from President Soekarno to President Soeharto.

The economic crisis that was experienced by Indonesia in the mid-1960s prompted the new government of President Soeharto to formulate a more open economic policy toward the global economy. In the investment policy, for example, Indonesia allowed the entry of foreign investment or multi-national companies in the national economic activities. Nevertheless, the state was still controlling the foreign companies by obliging them to hold local companies in the form of joint ventures and operate only in predetermined sectors. However, the sentiment of nationalism that emphasizes the role and intervention of the state in the economy tends to strengthen again as the country's financial capacity (1970 - mid-1980s) increases. Oil sustenance stimulated the country's ability to finance the industrialization of state directives, a national project that had also been proclaimed by President Soekarno. Oil and gas become the main sources of state revenue, in which, about 70 percent of state revenue came from oil and gas exports. The sharply increasing volume of state revenue was also possible due to oil and gas donations. Even the increase in the volume of state revenue contributed greatly to the formation of GDP. It was not surprising that during the oil boom years (1970s-1980s), the country became the prime mover of the Indonesian economic progress [2].

The economic crisis experienced by Indonesia in the mid-1980s and 1997 had also influenced the pattern of Indonesian economic policy. The liberal 
economist sees the economic crisis as a blessing in disguise for a more market-friendly economic policy. A series of economic liberalization policies issued by the government in overcoming the economic crisis. It further restricted the role and intervention of the state in economic activity, and thus provided an opportunity for market forces in the Indonesian economy. Economic liberalization had also encouraged the Indonesian economy to be more open toward the global economy. As Indonesia's national economy increased its integration with a wider economic domain, Indonesia was keen to play a bigger role through its involvement in regional economic cooperation forums. Indonesia and ASEAN countries are working to further deepen their economic integration through the establishment of the ASEAN Free Trade Area (AFTA) in 1992 and ASEAN Economic Community (AEC) in 2016. In fact, Indonesia has played an active role in using ASEAN as a collective vehicle in the face of the economic interests of the big countries. ASEAN is a regional platform to face the increasingly competitive global economic changes.

\section{CHALLENGES OF DEMOCRACY DURING POST-NEW ORDER ERA}

Indonesia experienced a remarkable economic progress, especially during the New Order regime. The astonishing economic progress characterized by the high and sustained economic growth that had enabled an extraordinary process of capital accumulation. The process of capital accumulation lasted for a period that emphasizes the importance of state participation and intervention in economic activity. Various incentives, such as licensing of government-provided subsidies and supported by a protectionist series of economic policies had enabled the birth of large national capital forces. The birth of capital forces in the Indonesian economy, therefore, was made possible by the intervention of the state. The state played a vital role in distributing rent through various incentives and financial protection. In this regard, rent-seeking activities were often seen as an essential feature of capital development. In an undeveloped market economy, protectionist policies to protect newly developed industries (infant industries) are not in conflict with the institutionalization of the market economy. However, the provision of financial protection (rent) has its limit. Concerning that, rent control is a very important issue in the market economy because the uncontrolled rent is a potential source of corruption practices.

The astonishing economic progress was made possible by the support of political stability and the presence of an authoritarian regime. Ironically, the economic changes experienced by the Indonesian as described earlier were not followed by the politicalchanges to end the authoritarianism. Economic growth was the source of legitimacy of the continual authoritarian regime. The economic crisis was the end of the New Order authoritarian regime. At that time, the political reform immediately implemented after the end of the New Order regime. Post-reformation, the changes in Indonesian politic was mainly characterized by the strengthening of the oligarchy [3]

This group is the old forces that took over the reformation process in order to maintain and even increase their own wealth. They want to be protected through the protectionist policies. Their success in reaching power had granted them with excellent access to the distribution of 'rent.' The interesting bit is that Indonesia's economic change that was in conjunction with the integration of the national economy into the more extensive economic system was not followed by significant political changes in promoting democracy and preventing the abuse of power practices. Indonesia had undergone dramatic political changes, such as the freedom to set up parties and highly competitive elections that significantly contributed to the electoral democracy. However, this dramatic changes which cause the inability to control rentseeking activities had considerably changed over time.

Another challenge of Indonesia' political change was the unsubstantial role of the civil society. It is like a missing element in the development of Indonesia's democracy. The diverse ethnicity, race, and religion create fertile ground for the movement of political support and competition. This condition divided the civil society and created the social fragment that weakened the opportunity for the society to voice their will for political change into the direction of democracy.

\section{References}

[1] Cohn, Theodore, Global Political Economy, New York: Longman, 2010

[2] Sjahrir, Kebijaksanaan Negara: Konsistensi dan Implementasi: Jakarta: LP3ES, 1987

[3] Robison, Richard dan Vedi R. Hadiz, Organizing Power in Indonesia: The Politics of Oligarkhy in An Age of Market, London \& New York: Routledge Curzon, 2004. 